\title{
Coronins and their role in immunological phenomena
}

\author{
BEATA TOKARZ-DEPTUŁA, MAGDALENA MALINOWSKA, MATEUSZ ADAMIAK, \\ WIESEAW DEPTUŁA
}

Department of Immunology, Faculty of Biology, University of Szczecin, Poland

\begin{abstract}
Coronins are a large family of proteins occurring in many eukaryotes. In mammals, seven coronin genes have been identified, evidencing that coronins 1 to 6 present classic coronin structure, while coronin 7 is a tandem coronin particle, without a spiral domain, although the best characterised coronin, in terms of both structure and function, is the mammalian coronin 1. It has been proven that they are related to regulation of actin dynamics, e.g. as a result of interaction with the complex of proteins Arp2/3. These proteins also modulate the activity of immune system cells, including lymphocyte $T$ and $B$ cells, neutrophils and macrophages. They are involved in bacterial infections with Mycobacterium tuberculosis, M. leprae and Helicobacter pylori and participate in the response to viral infections, e.g. infections of lymphocytic choriomeningitis virus (LCMV) and vesicular stomatitis Indiana virus (VSV). Also their involvement in autoimmune diseases such as lupus erythematosus has been recorded.
\end{abstract}

Key words: infections, coronins, immune system cells.

(Cent Eur J Immunol 2016; 41 (4): 435-441)

\section{Introduction}

Coronins are proteins with broad expression in the eukaryotic world. Bio-informatic analysis allowed 723 such particles to be identified in 358 species $[1,2]$. Coronins consist of amino-terminal tryptophan-aspartate residues, containing regions of repeats prior to the unique region of variable length that binds to carboxy-terminal spiral convoluted domains, which are necessary for their oligomerization [3, 4]. A "tandem" of coronins has also been described, formed of two WD cores, i.e. a large family of proteins, whose key role is to participate in creating protein complexes in almost all eukaryotic cell organelles. The proteins contain repeated regions that do not contain spiral domains [1, 5-7]. Seven coronin genes have been identified in mammals. It has been demonstrated that coronins 1 to 6 present the classic coronin structure, while coronin 7 is a tandem coronin particle without a spiral domain. The best characterized coronin, in terms of both structure and function, is the mammalian coronin $1[5,8,9]$. Coronins, which are located in the membrane, do not have trans-membrane domains. They only bind to the membrane with the cytoskeleton through interaction with cholesterol $[3,10,11]$.

Coronins are involved in the regulation of actin dynamics, e.g. coronin A isolated from the lower eukaryote Dictyostelium discoideum $[6,7,12,13]$ and coronins 1 and 4 occurring in mammal cells $[3,11]$ indicate association with
F-actin. For coronins 2 and 7, data point to their binding to F-actin [14], but there are also data not confirming this [15]. There is a lack of data on potential interaction of coronins 5 and 6 as well as 2 and 3 with F-actin. It was further found that coronin 1 is associated with a complex of proteins associated with actin - complex Arp2/3 [15, 16]. Given coronin interaction with the F-actin cytoskeleton of cells in the yeast Saccharomyces cerevisiae, invertebrates, as well as in mammals $[3,11,13,17]$, it is suspected that these proteins evolved from actin-binding particles in lower eukaryotes in order to become regulators of various cellular processes in mammals, determining and influencing the activity of the immune system and the immune response in viral and autoimmunological infections [18-20].

\section{Coronins and immune system cells}

The role of coronins in mammals in the area of immune mechanisms has been demonstrated e.g. in avoidance of the intracellular cidal property of Mycobacterium tuberculosis [21]. It is known that most pathogenic microorganisms are effectively eliminated by macrophages by phagocytosis ending with lysosomal destruction. In the case of $M$. tuberculosis, however, the bacterium stops this phenomenon by actively blocking lysosomal "supplies" [21], because $M$. tuberculosis bacteria undergoing phagocytosis are "stuck" in phagosomes, where they manage to

Correspondence: Beata Tokarz-Deptuła, Department of Immunology, University of Szczecin, 3c Felczaka St., 71-412 Szczecin, Poland, e-mail: kuki001@interia.pl

Submitted: 24.09.2015; Accepted: 6.01.2016 
survive for a longer time [22, 23]. It was found that during mycobacterial infection, a $51 \mathrm{kDa}$ protein is recruited and actively stored in the cytoplasmic part containing mycobacteria in macrophage phagosomes. This protein blocks the supply of phagosomes containing mycobacteria to lysosomal organelles, which prevents their destruction [24, 25]. Peptide sequencing of the isolated protein and cloning of cDNA that codes the protein showed the presence of a large central WD region that is typical for coronins. The region contains tryptophan-aspartate repeats, as well as its homologues of the previously identified p57 protein with unknown function, which were obtained together with phospholipase $\mathrm{C}$ from human leucocytes $[25,26]$. Based on the presence of the WD region and location of the $51 \mathrm{kDa}$ macrophage protein around phagosomes containing mycobacteria, the particle has been referred to as TACO, namely tryptophan-aspartate-containing coat protein [25]. Such facts and identification of several homological TACO particles [8, 9], genes of which were sequenced [27-29], have led to the conclusion that TACO and p57 are members of a protein family associated with coronins in yeasts and D. discoideum; hence presently it is assumed that TACO is coronin 1.

In mice, based on genetic ablation (a method involving DNA modification to interrupt the production of a specific gene), it was determined that coronin 1 is the cause of facilitated survival of mycobacteria in such animals' macrophages [30]. It was also evidenced that small RNA interruptions limiting regulation of coronin 1 in mice caused drastic reduction of mycobacteria in macrophages as a result of infection [31-33]. Apart from binding to phagosomes containing M. tuberculosis, coronin 1 also places itself near phagosomes containing $M$. leprae, which can also survive for a longer time in macrophage phagosomes of mice [34-36]. It is also assumed that Helicobacter pylori, like M. tuberculosis and M. leprae, is able to escape the immune response for a longer period of time. This is due to its survival by stopping lysosomal delivery. This shows that the role of coronin 1 is connected with the prevention of lysosomal supply in mammals infected with M. tuberculosis, M. leprae and H. pylori [37]. It is assumed that macrophages retained coronin 1 expression because of its key role in certain conditions for their function, or because the immune system of vertebrates maintained a store of mycobacteria in a closed subcellular space during evolution to use them as natural agents that allow for a quick immunological response $[38,39]$. This hypothesis is supported by the fact that liver macrophages are the only leucocytes with no expression of coronin 1 and due to evolutionary pressure on effective destruction of mycobacteria in the liver [40-43]. The studies on phagocytic activity of macrophages deprived of coronin $1[15,16]$ revealed that they do not show cytoskeletal defects and preserve their adherence and migration capacity, as well as chemotaxis and absorption capacity, i.e. fundamental phases of phagocytosis [30, 31, 33].
Recently, it has been demonstrated that coronin 1 is necessary to activate calcium signalling after the entry of mycobacteria into the macrophages, because absorption of these bacteria is associated with a transient increase in intracellular calcium ion concentration [30, 44-48]. This activates calcium-dependent calcineurin phosphatase [30, 49-51] - an enzyme of major importance for mycobacterial survival in macrophages [30]. Interestingly, the activation of calcium-dependent signalling after the uptake of mycobacteria turned out to be dependent on the expression of coronin 1 [30]. It was also found that if intracellular calcium ions are eliminated using chelating agents, the effect is the same as the removal of coronin 1 . In turn, if the intracellular concentration of calcium ions in coronin 1-negative macrophages increased, mycobacteria survived again [30] Therefore, it appears that the number of M. tuberculosis resistant to macrophage degradation is closely related to coronin 1-dependent activation of the calcium-calcineurin pathway. It was also found that despite the lack of defined coronin species specificity, coronin 1-deficient mice neutrophils showed no striking change of phenotype compared with wild mice type neutrophils, in the context of their development, migration ability, absorption and the NADPH oxidase-dependent killing activity of these cells [52].

Increased expression of coronin 1 in neutrophils and DC cells, together with reduced apoptosis of polymorphonuclear (PMN) cells, was recorded in human patients with cystic fibrosis [53-56]. It was also found that antigen processing and presentation by DC cells both to Th and Tc cells takes place correctly even in the absence of coronin 1 . Such data indicate that coronin 1 is redundant for antigen processing and presentation by dendritic cells and that $\mathrm{T}$ cell activity depletion, as well as lowered immune status of mice, is combined with coronin 1 deficiency [57]. In the case of mast cells, also differences in their functioning in the absence of coronin 1 were observed [58], although there are also data that do not confirm this observation [59], which suggests that such cells' dependence on coronin 1 may differ depending on the type. The role of this coronin was also found in NK cells [60], as this protein increases cytotoxicity of such cells through F-actin. If actin polymerisation is distorted by pharmacological inhibitors or its mutation, this results in NK cells' dysfunction.

In mice without coronin 1, a low number or absence of T-cells was recorded in peripheral blood, despite their normal growth in the thymus $[16,61,62]$. It was also found that principally absence of coronin 1 affects the pool of naive T-cells, as compared to effector and memory T-cells, both in the aspect of their absolute number and functionality. It is assumed that the engagement of coronin 1 in survival of naive $\mathrm{T}$ cells is related to its role in regulating F-actin, because in the absence of such protein, it accumulates in T cells, which is positively correlated with increased apoptosis of these lymphocytes. Therefore, it was assumed that the decrease of coronin 1 deficient T-cells 
occurs as a result of spontaneous apoptosis despite normal production of T-cells in the thymus [16]. It was evidenced that increased mortality of naive T-cells with coronin 1 deficiency is due to F-actin-induced distortions of mitochondrial membrane potential [16], although there are studies not confirming this $[18,62,63]$. It was also recorded that defects of the cytoskeleton in naive $\mathrm{T}$-cells resulting from deficiency of coronin 1 or caused by mutated coronin 1 are related to F-actin deregulation [16, 18, 62], although such changes have not been confirmed for B-cells [18, 62, 64], macrophages [30, 31, 33] or neutrophil granulocytes [65]. It was reported that deficiency of coronin 1 in naive $\mathrm{T}$-cells does not affect their membrane dynamics, formation of immunological synapses and talin polymerisation, or their migration activity [66]. It was, however, evidenced that the function of coronin 1 in naive T-cells is related to calcium signalling and movement of calcium ions [30, 63], because mobilisation of such ions and calcineurin activation are also the key for signal cascade activation of the T-cell receptor (TCR) [67], and their inhibition promotes apoptosis of such cells $[67,68]$. It was reported [17, 63, $64,68]$ that, in naive T-cells, mobilisation of calcium ions is greatly reduced if there is no expression of coronin 1 , or if there is expression of mutated coronin 1. Thus, it is assumed that the mobilization of calcium ions and activation of calcineurin provide pro-survival signals for $\mathrm{T}$ cells, although it has been demonstrated that coronin 1 deficient $\mathrm{T}$ cells have elevated levels of caspase 3 expression, which affects reduction of the level of pro-intravital molecules, as shown in the case of B cell lymphoma 2. This fact confirms the role of coronin 1 in T-cells in calcium-calcineurin signalling [66, 69-73]. This hypothesis is additionally supported by the fact that absence of naive T-cells, observed in the absence of coronin 1, has a similar effect as deletion of $\mathrm{A} \beta$ calcineurin in the absence of naive T-cells [74, 75]. It was also evidenced that both calcineurin activation and survival of such cells can be restored by increasing the intracellular concentration of calcium ions in T-cells with coronin 1 deficiency [18, 66].

Also, a practical insight into coronin 1 function in naive T-cells was provided by the analysis of Shionogi cataract (CTS) in mice with a major deficiency of T-cells in the peripheral blood, the phenotype of which is very similar to the one in knockout mice deprived of coronin 1 or its E26K mutation [71]. In mice with CTS, single positive thymocytes were observed which also showed distorted migration in the thymus, as well as defective mobilisation of calcium ions, although their survival rate was largely the same. It was also reported that, in the case of coronin 1, E26K mutants are delocalised in T-cells, which may contribute to their damaged migration capacity. It is assumed that such mutated protein is partially functional, which determines the mobilization and migration of calcium ions and survival of naive $T$ cells. The research has shown [76] that coronin 1 may be part of a signalling platform that requires supporting structures based on F-actin, to which coronin 1 may bind. Such activity through this platform may be responsible for the mobilization of calcium ions, which functions as an important stimulus for the survival of naive T lymphocytes. It is also possible that, apart from signalling cascade of TCRs, there is also another coronin 1-dependent trigger required in order to fully sustain the survival of nadve T-cells. It is currently assumed that the role of coronin 1 in T-cell survival is of major importance in reference to naive T-cells, because memory and effector T-cells survive well in the absence of coronin 1 . This assumption correlates with the role of coronin 1 in transmission of signals supporting TCR regulation in naive T-cells, which are proved to be necessary for survival of peripheral naive T-cells [77-80]. In turn, memory and effector T-cells, as well as regulatory T-cells, can survive even in the absence of peripheral stimulation by MHC particles [77, 79-83]. Such observations also indicate that molecular events underlying the signalling mediated by TCRs can differ in naive T-cells as compared to effector and memory T-cells. For example, in nadve T-cell signalling, strengthening signals are usually required to sustain their survival, whereas in the case of effector and memory T-cells, signalling is only required for their formation and survival [77, 79-83]. In reality, stimulation of TCRs in effector and memory $\mathrm{T}$-cells induces calcium ion mobilisation regardless of the coronin 1 expression, although the number of regulatory T-cells is normal and they are functional in the absence of coronin 1.

Coronin 1 is also required for complete mobilisation of calcium ions upon "triggering" the B-cell receptor (BCR). It is not, however, required for their survival and activation, probably because co-stimulation of such cell function largely, but not entirely, depends on the presence of coronin 1 [64]. Considering the fact that many coronins are co-expressed in leucocytes $[31,84]$, there is the question how necessary or unnecessary the presence of coronin 1 is. It has been shown that deletion of ubiquitously expressed coronin 2, which was considered important for cytoskeleton modulation [83], did not cause visible results in such cells. Furthermore, double knockout mice lacking both coronin 1 and 2 showed no effect on the phenotype, apart from a T-cell signalling defect caused by deletion of coronin 1 [61]. Although other known coronins can compensate for the loss of coronins 1 and 2, it is assumed that the major role of coronin 1 in calcium-calcineurin signalling mediated by TCRs, which is expressed in T-cells, cannot be compensated by any of them, as several cases of immunodeficiency associated with only mutations of coronin 1 have been described [20]. It was registered with immunodeficiency in humans, in the case of coronin 1 mutations in the paternal allele coupled with the deletion of the chromosomal mother's allele, although even in this case it must be assessed to what extent the observed defects were a result of coronin 1 dysfunction [20]. 


\section{Coronins vs. viral infections and auto-immunological diseases}

The role of coronins [52] was evidenced in mice with coronin 1 deficiency, where T-cell-dependent antiviral immunity was analysed during infection with lymphocytic choriomeningitis virus (LCMV) and vesicular stomatitis Indiana virus (VSV) [52]. It was found that for early control of infection with LCMV, a strong antiviral response of $\mathrm{CD}^{+} \mathrm{T}$-cells is necessary [53], while in the case of longterm antiviral immunity against LCMV, specific CD4 ${ }^{+}$ $\mathrm{T}$-cells and B-cells are required [54]. Immunity against such viral infection principally depends on type I interferons and early production of class $\mathrm{G}$ neutralising antibodies and the response of $\mathrm{CD}^{+}{ }^{+} \mathrm{T}$-cells and B-cells [58, 59, 85]. It was reported [52] that after infecting coronin 1 deficient mice with LCMV, elimination of viruses and induction of virus-specific $\mathrm{CD} 8^{+} \mathrm{T}$-cells were similar as in wild mice, which suggests a coronin 1-independent mechanism for T-cell activation, which is necessary to eliminate LCMV. Moreover, infection with this virus leads to normalisation of the range of peripheral CD8+ T-cells. Also, the response of CD4+ T-cells is significantly weakened as a result of infection with both LCMV and VSV, whereas activity of CD4+ T-cells and induction of B-cells are sufficient to maintain long-term control over infection with LCMV [2]. The authors also revealed that coronin deficient mice are very susceptible to infections with VSV due to the significant delay in the response of neutralising antibodies. The occurrence of nonsense homozygous mutations in coronin 1 has also been found in humans, determining susceptibility to infection with Epstein-Barr virus (EBV) [20].

Furthermore, the role of coronin 1 in auto-immunological diseases was observed in coronin 1-deficient mice immunised with a peptide originating from myelin oligodendrocyte glycoprotein (own antigen inducing experimental autoimmune encephalomyelitis [EAE] in wild mice) [86, 87]. It was observed that deletion of cyclin-dependent kinase 5 (CDK5 5) in haematopoietic cells of mice causes distorted activation of auto-reactive T-cells after infection with EAE, which is attributed to defective coronin 1 phosphorylation after the removal of CDK5 [87]. Also, in mice with coronin 1 deficiency, more severe symptoms of EAE were recorded after immunization than in the wild mice control group, which points to faulty activation of SMAD3 (mothers against decapentaplegic homolog 3 ) in $\mathrm{Th}_{17}$ cells - dependent on transforming growth factor $\beta$ - TGF $\beta$ [87-90]. Despite these facts, it is not clear whether coronin deficient mice immunity excitation after viral infection is due to the lack of a naive $\mathrm{T}$ cell or faulty signalling mediated by the TCR.

Further proof for the role of coronins in autoimmune diseases is the observation of a mutation in the coronin 1 gene, which inhibited the development of autoimmune disease in a mouse model of systemic lupus erythematosus
(SLE) [18]. In such animals, a mutation of coronin 1 was found, causing a phenotype inhibiting SLE. This was identified as a cytosine transition to thymine -784 in the coronin 1 gene, which led to transformation of a codon from glutamine to a stop codon $[18,91]$. Therefore mice expressing this coronin 1 mutant did not show any detectable expression of coronin 1 and are characterized by a significant reduction in the number of $\mathrm{T}$ cells $[18$, 92]. Also, the population of nadve T-cells in mice in the absence of coronin 1 points to a severe defect in calcium ion mobilisation after TCR stimulation [18]. It was also observed that after deletion of coronin 1, the autoimmune response was distorted, although immunity against foreign antigens remained at a normal level [64]. The authors explained that, despite the fact that conditions of selfimmunisation result from the deficiency of nadve T-cells in mice deprived of coronin 1, the antigen-related molecular processes that follow TCR activation can differ from the signals following stimulation by own antigens, which are coronin 1-dependent.

\section{Conclusions}

Coronins have been proved to play a role in reactivity of immune system cells, as well as in the immunological response to viruses and in autoimmune diseases; nevertheless, further studies are required to confirm their function in such processes in microorganisms.

\section{The authors declare no conflict of interest.}

\section{References}

1. Eckert C, Hammesfahr B, Kollmar M (2011): A holistic phylogeny of the coronin gene family reveals an ancient origin of the tandem-coronin, defines a new subfamily, and predicts protein function. BMC Evol Biol 11: 268.

2. Pieters J, Müller P, Jayachandran R (2013): On guard: coronin proteins in innate and adaptive immunity. Nat Rev Immunol 13: 510-518.

3. Gatfield J, Albrecht I, Zanolari B, et al. (2005): Association of the leukocyte plasma membrane with the aetin cytoskeleton through coiled coil-mediated trimeric coronin 1 molecules. Mol Biol Cell 16: 2786-2798.

4. Kammerer RA, Kostrewa D, Progias P, et al. (2005): A conserved trimerization motif controls the topology of short coiled coils. Proc Natl Acad Sci U S A 102: 13891-13896.

5. Rybakin V, Stumpf M, Schulze A, et al. (2004): Coronin 7, the mammalian POD-1 homologue, localizes to the Golgi apparatus. FEBS Lett 573: 161-167.

6. de Hostos EL (1999): The coronin family of actin-associated proteins. Trends Cell Biol 9: 345-350.

7. Rybakin V, CIemen CS (2005): Coronin proteins as multifunctional regulators of the cytoskeleton and membrane trafficking. Bioessays 27: 625-632.

8. Okumura M, Kung C, Wong S, et al. (1998): Definition of family of coronin-related proteins conserved between hu- 
mans and mice: close genetic linkage between coronin-2 and CD45-associated protein. DNA Cell Biol 17: 779-787.

9. Nakamura T, Takeuchi K, Muraoka S, et al. (1999): A neurally enriched coranin-like protein, Clipin $\mathrm{C}$, is novel candidate for an actin cytoskeleton-cortical membrane-linking protein. J Biol Chem 274: 13322-13327.

10. Gatfield J, Pieters J (2000): Essential role for cholesterol in entry of mycobacteria into macrophages. Science 288: 16471650.

11. Huang W, Ghisletti S, Saijo K, et al. (2011): Coranin 2A mediates actin-dependent de-repression of inflammatory response genes. Nature 470: 414-418.

12. de Hostos EL, Rehfuess C, Bradtke B, et al. (1993): Dictyostelium mutants lacking the cytoskeletal protein coronin are defective in cytokinesis and cell motility. J Cell Biol 120: 163-173.

13. de Hostos EL, Bradtke B, Lottspeich F, et al. (1991): Coronin, an actin binding protein of Dictyostelium discoideum localized to cell surface projections, has sequence similarities to G protein $\beta$ subunits. EMBO J 1: 4097-4104.

14. Cal L, Makhov AM, Bear JE (2007): F-actin binding is essential for coronin 1 B function in vivo. J Cell Sci 120: 17791790.

15. Cai L, Marshall TW, Uetrecht AC, et al. (2007): Coronin 1 B coordinates Arp2/3 complex and cofilin activities at the leading edge. Cell 128: 915-929.

16. Foger N, Rangell L, Danilenko DM, et al. (2006): Requirement for coronin 1 in $\mathrm{T}$ lymphocyte trafficking and cellular homeostasis. Science 313: 839-842.

17. Gaikin VE, Orlova A, Brieher W, et al. (2008): Coronin-1 A stabilizes $\mathrm{F}$-actin by bridging adjacent actin protomers and stapling opposite strands of the actin filament. J Mol Biol 376: 607-613.

18. Haraldsson MK, Louis-Dit-Sully CA, Lawson BR, et al. (2008): The lupus-related Lmb3 locus contains a disease-suppressing Coronin - 1A gene mutation. Immunity 28: 40-51.

19. Shiow LR, Paris K, Akana MC, et al. (2009): Severe combined immunodeficiency (SCID) and attention deficit hyperactivity disorder (ADHD) associated with a Coronin-lA mutation and a chromosome 16p11.2 deletion. Clin Immunol 131: 24-30.

20. Moshous D, Martin E, Carpentier W, et al. (2013): Whole-exome sequencing identifies coronin-1 A deficiency in three siblings with immunodeficiency and EBV-associated B cell lymphoproliferation. J Allergy Clin Immunol 131: 1594-1603.

21. Armstrong JA, Hart PD (1975): Phagosome-lysosome interactions in cultured macrophages infected with virulent tubercle bacilli. Reversal of the usual nonfusion pattern and observations on bacterial survival. J Exp Med 142: 1-16.

22. Russell DG (2001): Mycobacterium tuberculosis: here today, and here tomorrow. Nat Rev Mol Cell Biol 2: 569-577.

23. Pieters J (2008): Mycobacterium tuberculosis and the macrophage: maintaining a balance. Cell Host Microbe 3: 399-407.

24. Hasan Z, Schlax C, Kuhn L, et al. (1997): Isolation and characterization of the mycobacterial phagosome: segregation from the endosomal/lysosomal pathway. Mol Microbiol 24: 545-553.

25. Ferrari G, Langen H, Naito M, et al. (1999): A coat protein on phagosomes involved in the intracellular survival of mycobacteria. Cell 97: 435-447.

26. Suzuki K, Nishihata J, Arai Y, et al. (1995): Molecular cloning of a novel actin-binding protein, $\mathrm{p} 57$, with a WD repeat and a leucine zipper motif. FEBS Lett 364: 283-288.

27. Mouse Genome Sequencing Consortium, Waterston RH, Lindblad-Toh K, Birney E, et al. (2002): Initial sequencing and comparative analysis of the mouse genome. Nature 420: 520-562.

28. Lander ES, Linton LM, Birren B, et al. (2001): Initial sequencing and analysis of the human genome. Nature 409: 860-921.

29. Venter JC, Adams MD, Myers EW, et al. (2001): The sequence of the human genome. Science 291: 1304-1351.

30. Jayachandran R, Sundaramurthy V, Combaluzier B, et al. (2007): Survival of mycobacteria in macrophages is mediated by coronin 1-dependent activation of calcineurin. Cell 130: $37-50$.

31. Jayachandran R, Gatfield J, Massner J, et al. (2008): RNA interference in $\mathrm{J} 774$ macrophages reveals a role for coronin 1 in mycobacterial trafficking but not in actin.dependent processes. Mol Biol Cell 19: 1241-1251.

32. Kumar D, Nath L, Kamal MA, et al. (2010): Genome-wide analysis of the host intracellular network that regulates survival of Mycobacterium tuberculosis. Cell 140: 731-743.

33. Seto S, Tsujimura K, Koide Y (2012): Coronin-la inhibits autophagosome formation around Mycobacterium tuberculosis-containing phagosomes and assists mycobacterial survival in macrophages. Cell Microbiol 14: 710-727.

34. Suzuki K, Takeshita F, Nakata N, et al. (2006): Localization of CORO1A in the macrophages containing Mycobacterium leprae. Acta Histochem Cytochem 39: 107-112.

35. Sibley LD, Franzblau SG, Krahenbuhl JL (1987): Intracellular fate of Mycobacterium leprae in normal and activated mouse macrophages. Infect Immun 55: 680-685.

36. Montoya D, Modlin RL (2010): Learning from leprosy: insight into the human innate immune response. Adv Immunol 105: 1-24.

37. Allen LA, Schlesinger LS, Kang B (2000): Virulent strains oh Helicobacter pylori demonstrate delayed phagocytosis and stimulate homotypic phagosome fusion in macrophages. J Exp Med 191: 115-128.

38. Falkow S (2006): Is persistent bacterial infection good for your health? Cell 124: 699-702.

39. Janeway CA Jr. (1989): Approaching the asymptote? Evolution and revolution in immunology. Cold Spring Harb Symp Ouant Biol 54: 1-13.

40. Dory D, Echchannaoui H, Letiembre M, et al. (2003): Generation and functional characterization of a clonal murine periportal Kupffer cell line from H-2Kb-tsA58 mice. J Leukoc Biol 74: 49-59.

41. Wardle EN (1987): Kupffer cells and their function. Liver 7: 63-75.

42. Brandborg LL, Goldman IS (1990): Hepatology: A Textbook of Liver Disease. Saunders, Philadelphia; 1086-1098.

43. North RJ (1974): T cell dependence of macrophage activation and mobilization during infection with Mycobacterium tuberculosis. Infect Immun 10: 66-71.

44. Mendez-Samperio P, Palma-Barrios J, Vazquez-Hernandez A, et al. (2004): Secretion of interleukin- 8 by human-derived cell lines infected with Mycobacterium bovis. Mediators Inflamm 13: $45-49$

45. Mendez-Samperio P, Alba L, Trejo A (2007): Mycobacterium bovis-mediated induction of human beta-defensin-2 in epithelial cells is controlled by intracellular calcium and p38MAPK. J Infect 54: 469-474.

46. Mendez-Samperio P, Trejo A, Miranda E (2006): Activation of ERK1/2 and TNF- $\alpha$ production are mediated by calcium/ calmodulin, and PKA signaling pathways during Mycobacterium bovis infection. J Infect 52: 147-153. 
47. Rojas M, Garcia LE, Nigou J, et al. (2000): Mannosylated lipoarabinomannan antagonizes Mycobocterium tuberculosis-induced macrophage apoptosis by altering $\mathrm{Cah}+2$-dependent cell signaling. J Infect Dis 182: 240-251.

48. Carrithers LM, Hulseberg P, Sandor M, et al. (2011): The human macrophage sodium channel NaV1.5 regulates mycobacteria processing through organelle polarization and localized calcium oscillations. FEMS Immunol Med Microbiol 63: 319-327.

49. Winslow MM, Neilson JR, Crabtree GR (2003): Calcium signalling in lymphocytes. Curr Opin Immunol 15: 299-307.

50. Klee CB, Crouch TH, Krinks MH (1979): Calcineurin: a calcium-and calmodulin-binding protein of the nervous system. Proc Natl Acad Sci U S A 76: 6270-6273.

51. Stewart AA, Ingebritsen TS, Manalan A, et al. (1982): Discovery of a Ca2+-and calmodulin-dependent protein phosphatase: probable identity with calcineurin' [CaM-BP80). FEBS Lett 137: 80-84.

52. Tchanga VS, Mekker A, Siegmund K, et al. (2013): Diverging role for coronin 1 in antiviral CD4+ and CD8+ T cell responses. Mol Immunol 56: 683-692.

53. Fung-Leung WP, Kundig TM, Zinkernagel RM, et al. (1991): Immuneresponse against lymphocytic choriomeningitis virus infection in mice without CD8 expression. J Exp Med 174: 1425-1429.

54. Thomsen AR, Johansen J, Marker O, et al. (1996): Exhaustion of CTL memory and recrudescence of viremia in lymphocytic choriomeningitis virus-infected MHC class II-deficient mice and B cell-deficient mice. J Immunol 157: 3074-3080.

55. Moriceau S, Kantari C, Mocek J, et al. (2009): Coronin-1 is associated with neutrophil survival and is cleaved during apoptosis: potential implication in neutrophils from cystic fibrosis patients. J Immunol 182: 7254-7263.

56. Yan M, Di Ciano-Oliveira C, Grinstein S, et al. (2007): Coronin function is required for chemotaxis and phagocytosis in human neutrophils. J Immunol 178: 5769-5778.

57. Westritschnig K, Bosedasgupta S, Tchang V, et al. (2013): Antigen processing and presentation by dendritic cells is independent of coronin 1. Mol Immunol 53: 379-386.

58. Muller U, Steinhoff U, Reis LF, et al. (1994): Functional role of type I and type II interferons in antiviral defense. Science 264: 1918-1921.

59. Thomsen A, Nansen A, Andersen C, et al. (1997): Cooperation of $\mathrm{B}$ cells and $\mathrm{T}$ cells is required for survival of mice infected with vesicular stomatitis virus. Int Immunol 9: 1757-1766.

60. Mace EM, Orange JS (2014): Lytic immune synapse function requires filamentous actin deconstruction by coronin 1a. Proc Natl Acad Sci U S A 6: 6708-6713.

61. Föger N, Jenckel A, Orinska Z, et al. (2011): Differential regulation of mast cell degranulation versus cytokine secretion by the actin regulatory proteins coronin $1 \mathrm{a}$ and coronin $1 \mathrm{~b}$. J Exp Med 208: 1777-1787.

62. Arandjelovic S, McKenney KR, Leming SS, et al. (2010): Mast cell function is not altered by coronin-1A deficiency. J Leukoc Biol 88: 737-745.

63. Mueller P, Massner J, Jayachandran R, et al. (2008): Regulation of $\mathrm{T}$ cell survival through coronin-1-mediated generation of inositol-1,4,5-trisphosphate and calcium mobilization after T cell receptor triggering. Nat Immunol 9: 424-431.

64. Shiow LR, Roadcap DW, Paris K, et al. (2008): The actin regulator coronin $1 \mathrm{~A}$ is mutant in a thymic egress-deficient mouse strain and in a patient with severe combined immunodeficiency. Nat Immunol 9: 1307-1315.
65. Combaluzier B, Pieters J (2009): Chemotaxis and phagocytosis in neutrophils is independent of coronin 1. J Immunol 182: 2745-2752.

66. Mueller P, Liu X, Pieters J (2011): Migration and homeostasis of naive $\mathrm{T}$ cells depends on coronin 1-mediated prosurvival signals and not on coronin 1-dependent filamentous actin modulation. J Immunol 186: 4039-4050.

67. Gallo EM, Cante-Barrett K, Crabtree GR (2006): Lymphocyte calcium signaling from membrane to nucleus. Nat Immunol 7: 25-32.

68. Combaluzier B, Mueller P, Massner J, et al. (2009): Coronin 1 is essential for IgM-mediated $\mathrm{Ca}^{2+}$ mobilization in $\mathrm{B}$ cells but dispensable for the generation of immune responses in vivo. J Immunol 182: 1954-1961.

69. Kerstan A, Armbruster N, Leverkus M, et al. (2006): Cyclosporin A abolishes CD28-mediated resistance to CD95-induced apoptosis via superinduction of caspase-3. J Immunol 177: 7689-7697.

70. Mugnier B, Nal B, Verthuy C, et al. (2008): Coronin-1A links cytoskeleton dynamics to TCR $\alpha \beta$-induced cell signaling. PLoS One 3: e3467.

71. Ma A, Pena JC, Chang B, et al. (1995): Bclx regulates the survival of double-positive thymocytes. Proc Natl Acad Sci U S A 92: 4763-4767.

72. Motoyama N, Wang F, Roth KA, et al. (1995): Massive cell death of immature hematopoietic cells and neurons in Bcl-x-deficient mice. Science 267: 1506-1510.

73. Surh CD, Sprent J (2008): Homeostasis of naive and memory T cells. Immunity 29: 848-862.

74. Manicassamy S, Gupta S, Huang Z, et al. (2008): Requirement of calcineurin- $\alpha \beta$ for the survival of naive T cells. J Immunol 180: 106-112.

75. Bueno OF, Brandt EB, Rothenberg ME, et al. (2002): Defective $\mathrm{T}$ cell development and function in calcineurin-A $\beta$-deficient mice. Proc Natl Acad Sci U S A 99: 9398-9403.

76. Yagi H, Matsumoto M, Nakamura M, et al. (1996): Defect of thymocyte emigration in a T cell deficiency strain (CTS) of the mouse. J Immunol 157: 3412-3419.

77. Polic B, Kunkel D, Scheffold A, et al. (2001): How $\alpha \beta$ T cells deal with induced TCR $\alpha$ ablation. Proc Natl Acad Sci U S A 98: 8744-8749.

78. Labrecque N, Whitfield LS, Obst R, et al. (2001): How much TCR does a T cell need? Immunity 15: 71-82.

79. Takeda S, Rodewald HR, Arakawa H, et al. (1996): MHC class II molecules are not required for survival of newly generated $\mathrm{CD}^{+} \mathrm{T}$ cells, but affect their long-term life span. Immunity 5: 217-228.

80. Kirberg J, Berns A, von Boehmer H (1997): Peripheral T cell survival requires continual ligation of the $\mathrm{T}$ cell receptor to major histocompatibility complex-encoded molecules. J Exp Med 186: 1269-1275.

81. Tanchot C, Lemonnier FA, Perarnau B, et al. (1997): Differential requirements for survival and proliferation of CD8 naive or memory T cells. Science 276: 2057-2062.

82. Swain SL (2000): CD4 T-cell memory can persist in the absence of class II. Philos Trans R Soc Lond B Biol Sci 355: 407-411.

83. Murali-Krishna K, Lau LL, Sambhara S, et al. (1999): Persistence of memory CD8 T cells in MHC class I-deficient mice. Science 286: 1377-1381.

84. Zheng PY, Jones NL (2003): Helicobacter pylori strains expressing the vacuolating cytotoxin interrupt phagosome mat- 
uration in macrophages by recruiting and retaining TACO (coronin 1) protein. Cell Microbiol 5: 25-40.

85. Battegay M, Bachmann MF, Burhkart C, et al. (1996): Antiviral immune responses of mice lacking MHC class II or its associated invariant chain. Cell Immunol 167: 115-121.

86. Siegmund K, Zeis T, Kunz G, et al. (2011): Coronin 1-mediated naive $\mathrm{T}$ cell survival is essential for the development of autoimmune encephalomyelitis. J Immunol 186: 3452-3461.

87. Pareek TK, Lam E, Zheng X, et al. (2010): Cyclin-dependent kinase 5 activity is required for $T$ cell activation and induction of experimental autoimmune encephalomyelitis. J Exp Med 207: 2507-2519.

88. Kaminski S, Hermann-Kleiter N, Meisel M, et al. (2011): Coronin $1 \mathrm{~A}$ is an essential regulator of the TGF $\beta$ receptor/ SMAD3 signaling pathway in Th17 CD4 ${ }^{+} \mathrm{T}$ cells. J Autoimmun 37: 198-208.

89. Bettelli E, Oukka M, Kuchroo VK (2007): $T_{H} 17$ cells in the circle of immunity and autoimmunity. Nat Immunol 8: 345350.

90. Weaver CT, Hatton RD, Mangan PR, et al. (2007): IL-17 family cytokines and the expanding diversity of effector $\mathrm{T}$ cell lineages. Annu Rev Immunol 25: 821-852.

91. Hogquist KA (2008): Immunodeficiency: when T cells are stuck at home. Nat Immunol 9: 1207-1208.

92. Santiago-Raber ML, Haraldsson MK, Theofilopoulos AN, et al. (2007): Characterization of reciprocal Lmb1-4 interval MRL-Fas ${ }^{l p r}$ and C57BL/6-Fas ${ }^{l p r}$ congenic mice reveals significant effects from Lmb3. J Immunol 178: 8195-8202. 